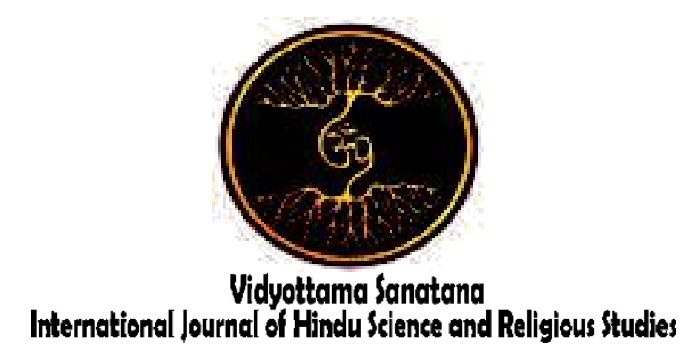

Vol. 3 No. 1 May 2019

\title{
THE LOCAL WISDOM VALUE OF MANDHASIYA TRADITION (Study of Hindu Education)
}

\author{
By: \\ Heny Perbowosari \\ Institut Hindu Dharma Negeri Denpasar \\ E-mail : henysari74@gmail.com
}

Received: February 2, 2019

Accepted: May 11, 2019

Published: May 31, 2019

\begin{abstract}
Mandhasiya tradition is one of the local wisdom that is still carried out by the Gumeng Village community in Jenawi District, Karanganyar Regency. This tradition is believed by the community as a sacred and religious meaning, so the community is still encouraged to carry out this ritual. This study aimed at describing the reasons of Gumeng villagers to keep maintaining the Mandhasiya tradition, especially the local wisdom value of the Mandhasiya Tradition in the study of Hinduism education in Gumeng Village, Jenawi District, Karanganyar Regency and the implications of the Mandhasiya tradition toward Hindu communities in Gumeng Village, Jenawi District, Karanganyar Regency.

This study used a qualitative method with a socio-cultural phenomenology approach. The primary data were collected by direct observation and interviews, while the secondary data by the exploration of journals, research results, and relevant literature sources. The results of this study concluded that 1) The reason to keep maintaining the Mandhasiya tradition by the Gumeng village community in Jenawi Subdistrict, Karanganyar Regency because of the desire to preserve the Javanese culture, ask for salvation to the Almighty God, maintain harmony among people, as well as trust in myths 2) Mandhasiya tradition have values of local wisdom based on the study of Hindu religious education, they are: religious values (Sraddha), togetherness values (Tat Twam Asi), environmental preservation values (Tri Hita Karana), sincerity values (Yajna), 3) implications of the Mandhasiya Tradition toward the society in Gumeng village, Jenawi Subdistrict, Karanganyar Regency is strengthening the community religiosity, strengthening solidarity, being involved in collective worship, and creating community welfare.
\end{abstract}

Keywords: Local Wisdom, Tradition, Mandhasiya 


\section{Introduction}

Local wisdom is one of the views of the Javanese community. It is a religious morality attitude and ethics. According to Geertz (2007) in Ernawi (2010), local wisdom is an entity that greatly determines human dignity in the community. Javanese society is seeking their identity through the harmony between spiritual and physical so that they will be able to realize themselves as a whole and thoroughly, and be able to maintain the ethics prevailing in society.

Society is a place to grow and develop a tradition. Besides, tradition is also as part of the culture. Tradition is a ritual activity that involves all citizens of the community with the aim of obtaining safety. The attitude and behavior carried out by the community so that it becomes a tradition. This is due to the existence of the basic values that are believed to be true by the community as a manifestation of local wisdom (Basyari, 2014). Moreover, Sztompka (2007) states that tradition can be interpreted as a true inheritance of the past. However, the tradition carried out repeatedly is not accidental or intentional. Tradition is a social institution that is not written, but the community must recognize and comply with the guidelines in behavior. So, the community does not deviate from the applicable rules. In addition, tradition is also a means of communication between humans and humans, humans and their creator, and humans in protecting the surrounding environment. Thus, this tradition is a media of socialization, where messages and values upheld by the community will be conveyed to the next generation. Considering the importance of tradition, it is necessary to maintain, excavate and fertilize, so as not to fade and just disappear.

One tradition that is still maintained by the community is the Mandhasiya tradition. It is one of the local wisdom that is still carried out by the Gumeng Village community in Jenawi Subdistrict, Karanganyar Regency. This tradition is believed by the community as sacred and contains religious meaning, so the community is still encouraged this ritual.

This Mandhasiya tradition is carried out every seven months in the form of a clean village which is held every Tuesday Kliwon wuku Mandhasiya (Java). The purpose of the implementation of this tradition is as a means of control of behavior related to the relationship between humans and God, humans and humans, and humans and the universe. This is a connection between the Mandhasiya tradition carried out by the Javanese people and the teachings in Hinduism namely Tri Hita Karana. In this teaching, there is the existence of Parahyangan (relationship between humans and God), Pawongan (relationship between human and human), and Palemahan (relationship between humans with the universe).

The implementation of this tradition is considered important by the Gumeng villagers as a socio-cultural development of the community. It is because this tradition as a guide to norms and values of local wisdom. The implementation of this tradition is expected to increase security for its citizens. Besides, it is also used as a guide in determining attitudes and behavior in everyday life. Gumeng Village Community, Jenawi Sub-District, Karanganyar Regency still believes that by carrying out this tradition there will be no riots in the area and begging for their lives to prosper and have fertile nature, such as the Javanese philosophy that says gemah ripah loh jinawi toto tentrem kerto raharjo which means abundant natural wealth and peaceful conditions.

\section{Method}

This study used a qualitative method with a socio-cultural phenomenology approach because it is to obtain empirical experience relating to the Mandhasiya tradition in the Gumeng village community, Jenawi District, Karanganyar Regency. As Iskandar (2010: 24) explains that a sociocultural phenomenology approach is an approach that uses observations of natural 
phenomena and is used as a data source or reality-based approach (empirical).

The data collection techniques in this study used interviews with informants, direct observation, and documentation. While the data analysis technique used an interactive model (Miles, 1992). The data acquisition stages are as follows: collecting data, reducing data, presenting data, and drawing conclusions.

\section{Results And Discussion}

\subsection{The Profile of Gumeng Village Community, Jenawi District, Karanganyar Regency}

Gumeng Village, Jenawi Subdistrict, Karanganyar Regency is an area that has a farming typology and plantation around 6,665 hectares (village monograph in 2017). Gumeng village is also a tourist village because in this village there is a Hindu heritage temple named Cetho Temple. Gumeng Village is headed by a village head and is assisted by several village officials. Most Gumeng villagers have a livelihood as farmers, but with the increasing number of visitors to the tourist area of Cetho Temple, there are some people who work as employees in the tourist area.

The majority of Gumeng villagers are mostly Hindus, but tolerance is very good for the people. This can be seen from the activities of the community in carrying out the ritual activities of the Mandhasiya tradition, both those who are Hindus, Muslims, and Christians who blend together in the procession of activities.

\subsection{Mandhasiya Tradition in Gumeng Village, Jenawi District, Karanganyar Regency}

Traditions are born in two ways. The first way is emerging from below through the mechanism of emergence spontaneously and unexpectedly and involving many people who have a sense of awe and turn into behavior in the form of ceremonies, research, and reinterpret old beliefs. All these actions strengthen attitudes. That is how tradition is born. The second way arises from above through coercive mechanisms. Something considered as tradition is chosen and made public attention or forced by influential or powerful individuals (Sztompka, 2011: 6970).

The tradition according to the Great Dictionary of Indonesian Language is the product of human creations and works, material objects, beliefs, fantasies, events that are inherited from one generation to the next (Ministry of Education and Culture, 1990). Tradition is a description of human attitudes and behaviors that have been going on for a long time and carried out for generations starting from the ancestors. According to Anggoro (2012), the origin of the Mandhasiya word is closely related to the pawukon name adopted by the Javanese at that time, where the Javanese people knew pawukon by adopting the stories of Prabu Watugunung and Dewi Sinta who gave birth to 28 children so that the child's name became the name of his/her father in Java, and one of them is the Mandhasiya temple. So that the Mandhasiya Tradition will be held on Tuesday Kliwon wuku Mandhasiya.

The Gumeng villagers before carrying out the Mandhasiya tradition, which was precisely on Monday Wage morning, made preparations by installing banners, making penjor and a place for staging puppets. In addition, the community also prepared facilities for offerings from home. The villagers carried tenong / tenggok containing: tumpeng agung (nasi uduk), eggs, crops, fruits, kembang liman, kupat lepet, and market snacks.

On Monday Wage, in the afternoon, the Hindus held a joint prayer led by Pinandita. Then the next day, precisely on Tuesday Kliwon wuku Mandhasiya, a good community of Hindus, Muslims, and Christians flocked to the courtyard of Cetho Temple to conduct a joint prayer led by Traditional Elders.

The implementation of this tradition took place in the morning from 08.00 to 11.00. The place for carrying out the Mandhasiya tradition was done at Cetho Temple on the fifth level because there were 
punden berundak in the Krincing Wesi Studio. After the community had finished doing the prayer together, they took offerings that had been given and then distributed equally to all the citizens and enjoyed fairly and evenly. After the worship procession was completed, this activity was continued in the afternoon by holding a puppet show by calling the local puppeteer.

\subsection{Reasons of Gumeng Village Communities Still Maintaining the Mandhasiya Tradition}

As citizens, they usually tend to defend themselves for survival. Therefore, culture is needed. With the existence of culture, humans will have provisions in fulfilling a life. According to Kluckohn in Suparlan (1984), culture is a collection of references and human grip in adjusting to the environment. Thus, through living together, the community will have the same habits, both in terms of behavior, norms, and customs.

One of the habits carried out by the community is a tradition carried out from generation to generation. Like the Gumeng Village community in Jenawi District, Karanganyar Regency, which until now still maintains the Mandhasiya tradition, which is believed to have functions that are quite useful for the community and the truth. The reasons for the Gumeng villagers still maintain this tradition because of several reasons since this tradition has several functions, including:

\subsubsection{Preserving Javanese Culture}

Ranjabar (2006) argues that the preservation of local culture is a way to maintain cultural art values and traditional values by developing dynamic manifestations and can adjust situations and conditions that are always changing and developing. The culture of an area is a civilization in people's lives. Javanese culture has various aspects which reflect behavior, rules, and order in life. The order of life in Javanese culture has great values. However, at this time Javanese culture has undergone a shift due to the current of globalization. Therefore, in order to keep Javanese culture steady, it needs to be preserved. Preservation of local culture is an effort to preserve cultural art values and traditional values by developing dynamic manifestations and adjusting to situations and conditions that are always changing and developing (Ranjabar, 2006).

According to Sujamto (1992), cultural preservation includes seven elements, they are: (a) religion and religious ceremonies; (b) community organizations; (c) knowledge systems; (d) language; (e) art; (f) livelihood or economy; and (g) technology systems. Preservation of Javanese culture directly involves preservation of the seven elements.

Cultural preservation in the Mandhasiya tradition is a social function of a custom. Tradition is as a form of culture that contains noble values, such as the Gumeng village community in Jenawi District, Karanganyar Regency, which still preserves the Javanese cultural heritage by implementing the Mandhasiya Tradition. The Mandhasiya tradition is a religious activity carried out by the villagers every six months precisely at the Mandhasiya temple.

This is in accordance with the statement from Bayan village Cetho, that: "This Mandhasi tradition has been carried out since a long time ago and does not know when the beginning of this tradition was carried out ... This tradition is carried out every six months precisely at the Mandhasiya temple" (interviewe, June $19^{\text {th }}$, 2018).

Based on the results of the interview above, this Mandhasiya tradition is a legacy that has been carried out from a long time ago, which is a legacy of ancestors. This Mandhasiya tradition is an earlier cultural heritage in which the former community became a source of the cultural formation so that a tradition which became hereditary and passed on to the next generation. This Mandhasiya tradition is always done every six months, according to the Javanese Pawukon. This Mandhasiya tradition is held 
every Tuesday Kliwon wuku Mandhasiya, where this event coincided on June $19^{\text {th }}$, 2018.

Gumeng villagers believe that the Mandhasiya tradition is inherited from their ancestors and is believed to have a significant role in people's lives, so it needs to be carried out and preserved its authenticity and cultural preservation. As revealed by Teguh (interviewe, July $21^{\text {st }}$, 2018) "the Mandhasiya tradition originates from the previous preaching, where all of it teaches about good things, and nothing bad. So, we should we as the next generation should maintain and preserve this tradition".

Based on the above expression, it can be concluded that the Mandhasiya tradition has a positive impact on the Gumeng village community, namely the existence of prosperity in the community, so this needs to be maintained and preserved.

\subsubsection{Requesting Salvation to God Almighty}

The Mandhasiya tradition is basically a form of gratitude to God because the Gumeng villagers have been given prosperity from plantation products obtained in a year such as vegetables, shallots, tea leaves, as revealed by Bayan Gumeng village, "This Mandhasiya tradition is carried out by the villagers in the form of gratitude to God so that the plantation products are well preserved".

Thus, the tradition carried out by the community is essentially a custom to obtain peace and safety of life as an embodiment of the limited ability of humans to face life's challenges, both from themselves and their natural surroundings. This Mandhasiya tradition is carried out by the community with the aim of making direct contact with the ancestors, spirits, gods and also with the Almighty God.

This Mandhasiya Tradition is a ritual performed by the Gumeng village community with the aim of obtaining safety and prosperity. The implementation of this tradition is an expression of gratitude for all the gifts that God has given. The Gumeng village community has the belief that by doing this tradition it means joining in and praying for salvation and prosperity while staying awake.

This Mandhasiya tradition is carried out by the Gumeng villagers through communication with God in the form of praying together to express their gratitude for all the gifts that God has given them in the form of safety, health, and fortune in the year, and to request that in the following year the plantation yields increase fertile.

Thus, the Mandhasiya tradition has been carried out since the ancestors by offering offerings as a form of gratitude, and plead with God Almighty that hopefully will be given safety and prosperity, like the Javanese proverb gemah ripah loh jinawi toto tentrem kerto raharjo.

\subsubsection{Maintaining Harmony between Communities}

In developing a harmonious and peaceful life for multicultural communities, the people in Gumeng village implement the Mandhasiya tradition, which is one of the local wisdom that can build awareness in diversity. In this Mandhasiya tradition, there are several activities that require people to socialize and communicate with each other which indirectly fosters harmony in the community.

The Mandhasiya tradition in Gumeng village is related to interfaith relations which is based on the knowledge of manners in social interaction, this interaction between religious communities in Gumeng village reflects how religion is functioned in a social context. This social relationship is formed because of the willingness of the community to establish togetherness and not conflict with prevailing social values.

This Mandhasiya tradition is a tradition that strongly promotes tolerance among religious people in Gumeng village, where the implementation of the Mandhasiya tradition is carried out by various religions, including Islam, Christianity, and Hinduism based on mutual cooperation and helping each other to 
increase solidarity among citizens so as to create harmony. In mutual cooperation activities carried out jointly by citizens without discriminating religion.

Through this tradition, Gumeng villagers try to communicate and interact to build a strong sense of brotherhood. As the results of the interview stated by Teguh (July $20^{\text {th }}$, 2018): "This Mandhasiya tradition is carried out by all people in Gumeng village, including Hindus, Christians, and Muslims. They mingled together to do a joint prayer held in the courtyard of Cetho Temple ".

Based on the above explanation, Gumeng villagers have a strong tolerance to maintain brotherhood among religions, they feel that although they are different in religion, there will be mutual respect among fellow religious people. Thus the indicators in harmony include the presence of religious tolerance. There is a good relationship between people and religious groups so that they maintain tolerance in the Gumeng village community.

\subsubsection{There is Public Confidence in the Myth}

According to Endraswara (2003), myths give the color of life to the Javanese. Apart from that, in the life of the Javanese people, it was greatly influenced by myths. People believe in the existence of myths because humans have imaginations originating from cultural roots and myths which are considered sacred. According to Mircea in Honko (1984), one of the functions of myth is to build a model of behavior and through the myths society will get religious experience. In addition, according to Campbell (1998), there are several functions of myth, they are: (a) mystical function: the existence of admiration for the universe, (b) cosmological function: explain the shape of the universe, (c) sociological functions: the existence of legality about social order, (d) pedagogical functions: explain how humans live their life.

For Gumeng villagers, the belief in this myth becomes a force that is manifested in the form of rituals and offerings and shadow puppets that have a function to maintain the balance of nature. Gumeng villagers still have the belief that by taking care of the surrounding environment it will have an influence on their lives. With such trust, the local community respects by carrying out a tradition which has the aim of safeguarding the safety of the village and avoiding the village from danger. Besides this tradition also aims to express gratitude to God Almighty.

3.4 Local Wisdom Values of the Mandhasiya Tradition in Hindu Religious Education Studies

\subsubsection{Religious Value (Sraddha)}

Religion is an attitude and behavior that shows the belief in the power of the Creator or the Almighty God. A person's belief is a behavior about obedience in following orders and avoiding all His prohibitions. This is realized by being obedient in worshiping and behaving in accordance with what has been regulated by religion and not doing what is forbidden by religion (Titib, 1996: 67)

This religious value in the Mandhasiya tradition is a form of belief (Sraddha) for the existence of the Almighty God (Ida Sang Hyang Widhi Wasa) which is indicated by the activity of expressing gratitude for the creation of the universe and its contents and gratitude for all life and salvation that has been given. It is as stated in the Book of RgVeda VIII.1.3 as follows:

Yac cid hi tva jana ime

Nana havanta utaye

Asmakam brahmedam Indra

Bhutute, aha uisva ca vardhanam

Meaning:

Sang Hyang Indra (The Almighty God); mankind, during an emergency, begs you with variety for their salvation. May prayers that glorify You will be granted (Titib, 1996: 175).

This verse explains that the existence of the Almighty God is also a protector of living things including humans in carrying out their lives. Hinduism teaches that God 
exists in every case and in all situations, so that humans need to get closer to Him, so that they can create a sense of security. On this basis, human beings carry out religious activities, such as those carried out by the Gumeng villagers in the Mandhasiya tradition by praying.

To begin the procession of the Mandhasiya tradition, a stakeholder-led prayer meeting was held with the aim that the implementation of this tradition can run smoothly and invoke salvation, this was carried out based on sincerity as a form of devotion and gratitude. This prayer began one day before the implementation, precisely on Monday night specifically Hindus held a prayer together in the courtyard of Cetho Temple (interview with Jro Mangku Gede on June $20^{\text {th }}, 2018$ ). Then on Tuesday Kliwon, it was held a procession culminating in the Mandhasiya tradition, where all the citizens of both Hinduism, Islam, and Christianity came to the court of Cetho Temple by conducting a joint prayer led by the local Customary Elders.

\subsubsection{Togetherness Value (Tat Twam Asi)}

Togetherness means a bond that is formed because of a sense of family or brotherhood. In togetherness there are four elements that need to be created and maintained and carried out by individuals, they are: (1) one heart and one mind (having the same vision), (2) unselfish, (3) humble, and (4) willing to sacrifice. This togetherness is formed from a sense of kinship and togetherness that can create a sense of mutual respect, and care. With this sense of togetherness, the community will be able to help each other, a sense of empathy in community life.

Apart from that, in the teachings of Hinduism the concept of togetherness is better known as Tat Twam Asi. This teaching order us not to hurt each other with all of God's creations. According to Suciartini (2017), Tat Twam Asi is the key to being able to foster humans so that harmonious relationships can be established on the basis of sharpening, nurturing, and fostering among fellow human beings. In the daily life of the teachings of Tat Twam Asi, this can be implemented by the way every parent always teaches and gives examples to always respect others.

In the Mandhasiya tradition, the values of togetherness are very emphasized (Tat Twam Asi) in the implementation of tradition as the results of interviews with the Head of Gumeng Village (July $21^{\text {st }}, 2018$ ) that: "Before implementing the Mandhasiya tradition, the Gumeng villagers worked together to clean up the area of the procession and make equipment in processions such as making penjor, decorations, and places for puppet shows".

Based on the results of the interview above, all good citizens who are Hindus, Christians, and Muslims work together to clean up the courtyard area in Cetho Temple. They do mutual cooperation without coercion from anyone. In this case, there is an understanding that they have that by implementing the Mandhasiya tradition, the citizens will be more familiar and cooperate so that the sense of togetherness will always be nurtured by local residents.

All Gumeng villagers have a fairly high sense of togetherness, this is seen by residents volunteering to contribute to the implementation of the Mandhasiya tradition. They are happy to contribute so that the implementation of this tradition can run smoothly. As well as during the procession of the Mandhasiya tradition, this sense of togetherness was increasingly seen, all residents, including Muslims, Christians, and Hindus flocked to bring offerings to the court of Cetho Temple to be offered. After the procession is complete, they share the provisions (offerings) that they bring without seeing religion, they jointly enjoy food brought from home.

\subsubsection{Environmental Conservation Value (Tri Hita Karana)}

The attitude of preserving the environment really needs to be planted in the community. This is because in this era of globalization, technology is increasingly 
advanced and increasingly densely populated, while also decreasing public awareness in managing the environment. This can be seen from community behavior such as littering, resulting in flooding, cutting down trees, and not replanting, this will result in landslides. In addition, the use of cooling machines has resulted in global warming.

The attitude of preserving the environment is very necessary to maintain human life. The attitude of preserving the environment is done to prevent damage to the environment and develop attitudes to repair environmental damage. This attitude to preserve the environment can be done by maintaining environmental cleanliness. According to Ernawi (2010), the rituals carried out by the Javanese people are very closely related to nature such as: the ritual of salvation where this ritual invites blessings to spirits waiting for a certain place in order to avoid catastrophe, clean village rituals as a form of gratitude for the gifts given by God Almighty, and directly teaches the community to preserve the natural environment.

Preserving this environment in the teachings of Hinduism is known as Tri Hita Karana, where the meaning of the concept is three harmonious relationships, which consist of Parahyangan namely the relationship between humans and God, Pawongan means the relationship between humans and humans, and Palemahan means the relationship between humans and environment (Wiana, 2007: 6). One of the concrete manifestations of human relations with nature is the attitude to preserve the environment. In implementing the environmental preservation, it can be realized in the form of a yajna such as the implementation of this Mandhasiya Tradition. The implementation of the Mandhasiya tradition has the purpose of expressing gratitude to Ida Sang Hyang Widhi Wasa and cleaning the natural environment in a way that is one form of attitude to preserve the environment (Soares \& Sudarsana, 2018).
The implementation of the Mandhasiya tradition carried out by the Gumeng village community in Jenawi Subdistrict, Karanganyar Regency shows an attitude to preserve the environment. This is based on the results of observations made on June $18^{\text {th }}, 2018$, where prior to the implementation of the Mandhasiya tradition, voluntary work was carried out first by cleaning up the area in the courtyard of the Cetho Temple. The cleaning activity was carried out jointly by the Gumeng villagers. In addition, clean-up activities were also carried out after the completion of the Mandhasiya tradition.

\subsubsection{Sincerity Value (Yajna)}

In implementing this Mandhasiya tradition, the community did it full of sincerity and full of pleasure. Gumeng villagers believe that offerings made sincerely and based on a clean heart will undoubtedly God receive their offerings, Sincerity in the teachings of Hinduism is often referred to as Yajna. Ngurah (1998) states that Yajna is the embodiment of Vedic teachings. With Yajna, humans can develop and maintain their lives. Sincerity and purity of self are the main basis in expressing gratitude to God for the gifts that have been given.

The Gumeng village community in carrying out the Mandhasiya tradition always strives for the best, for example, people outside the Gumeng village come in droves to the village to carry out the sacred procession, besides the community also sincerely collects funds for the implementation of the tradition. and they invited relatives to attend the procession by offering offerings (interview, Hery Suwardi, July $19^{\text {th }}, 2018$ ).

In addition, Kasman also stated that in carrying out the Mandhasiya tradition, the Gumeng villagers also taught their children to participate in this activity. Because they want their children not to forget the traditions that are inherited from their ancestors. And teaching them to learn is based on a sense of sincerity and sincerity, 
so it will develop children's personality. By making offerings during the procession of the Mandhasiya tradition, they express their gratitude for the gift given to the Almighty God.

\subsection{The Implications of the Mandhasiya Tradition towards the Gumeng Village community}

The implementation of the

Mandhasiya tradition in Gumeng village has useful implications for people's lives, both religious, social and cultural. The implications of the Mandhasiya tradition for the Gumeng village community are as follows:

\subsubsection{Strengthening Community Religiosity}

Religiosity is the depth of a person in believing in a religion accompanied by a level of knowledge of religion that is manifested in the form of practicing religious values by obeying the rules and carrying out their obligations wholeheartedly and sincerity in daily life. According to Dister (1991), religiosity is diversity because of the internalization of religion into a person. In the implementation of the Mandhasiya tradition in Gumeng village, Jenawi Subdistrict, Karanganyar Regency had an impact on the increasing religious level in the community. As stated by Bawani (1985) that religiosity or religious attitude as a process in the soul (spiritual) to direct someone in everyday life both in terms of feelings, thoughts, and dreams to carry out trust in God. Thus, this religiosity is a combination of the belief in God, feelings towards religion and behavior in carrying out religious teachings.

With the implementation of the Mandhasiya tradition, it was seen that there was a religiosity of the Gumeng villagers where they held a joint prayer activity on Hindus which was held a day before the procession of the Mandhasiya tradition. This happened because of the understanding of the Gumeng villagers who were Hindus that by worshiping the Almighty God they would be given prosperity and salvation. This was also explained by Jalaludin (2007) that a person is religious because they depend on God Almighty (sense of depending) so that they always perform rituals to ask for salvation.

According to Teguh (interview, June $19^{\text {th }}, 2018$ ) that Gumeng villagers have faith if they do this tradition, they will always be given prosperity.

\subsubsection{Strengthening the Sense of Solidarity}

The Mandhasiya tradition in Gumeng village, Jenawi District, Karanganyar Regency is carried out to preserve the culture and as an expression of gratitude for everything that has been given to the village and the community so that the situation in Gumeng village remains safe, peaceful, and prosperous. Thus, the Gumeng village community is very enthusiastic about carrying out this Mandhasiya tradition every six months and the community is happy to participate in the implementation of this tradition. Therefore, the implementation of the Mandhasiya tradition has an impact to strengthen the sense of solidarity of the Gumeng village community. This can be seen from the involvement of the community from the preparation stage to the procession stage.

According to Doyle (1998), solidarity emphasizes the relationship between individuals and groups based on a shared attachment in life that is supported by moral values and beliefs that are ingrained in society. The real manifestation of a joint relationship will result in an emotional experience, thus the relationship between community members will be even tighter. The activities carried out by Gumeng villagers in strengthening their sense of solidarity include:

\section{1) Deliberation}

In the implementation of the Mandhasiya tradition, this usually begins with the involvement of the community through deliberations involving various parties ranging from the level of the 
Neighborhood Unit to the village apparatus. Usually, during the deliberations, this is done from the village level and then passed to the hamlet level. This is explained by one of the research subjects that this meeting is something that needs to be done so that the implementation of the Mandhasiya tradition can run well. Like the statement given by Teguh Pambudi as follows:

Before implementing the Mandhasiya tradition, it was necessary to hold a meeting first, lady. The village head usually invited village officials and community representatives. In this deliberation, we express each other's opinion on the smooth implementation of this procession.

Thus, the implementation of this deliberation is considered important by the community since the existence of this meeting will get an agreement in implementing this tradition so that the procession of this tradition can run smoothly and in accordance with expectations.

\section{2) Shared Contributions}

Gumeng villagers always celebrate this Mandhasiya tradition every seven months precisely at the Mandhasiya temple, and in this implementation, it always goes well and smoothly. In the procession of tradition this is usually carried out in the morning by praying together in the courtyard of the Cetho Temple, then at night entertainment is held in the form of shadow puppet shows.

In order for the implementation of the tradition to run well, funds are needed. These funds were obtained from voluntary contributions from all residents of the Gumeng village community. In determining the number of contributions from the community through consultation. Thus, the community feels happy to contribute funds so that this tradition is carried out properly. According to Mr. Warto (interview on July $\left.19^{\text {th }}, 2018\right)$ that "to implement this tradition it is usually the community that donates at least Rp. 150,000.00 (one hundred and fifty thousand rupiahs), but some people who have good agricultural businesses contribute more than that.

In addition, according to Teguh Pambudi (interview, July 19 ${ }^{\text {th }}, 2018$ ), the Gumeng villagers are always happy and sincere to pay contributions in carrying out this tradition because they feel comfortable.

Based on the results of the interviews above, the Gumeng villagers felt they had an obligation to pay contributions to the implementation of the Mandhasiya tradition, but they did not feel compelled to pay this fee. Residents are very enthusiastic and sincere to pay this fee so that this tradition can run well and smoothly. Because according to the beliefs of the people in Gumeng village if this tradition goes well and smoothly they will get prosperity.

\section{3) Engaging in Collaboration Together}

Gumeng village community is carrying out their Mandhasiya tradition with full voluntary and enthusiastic. This can be seen at the time of carrying out joint prayers, both those who are Muslims, Christians, and Hindus. In the ceremony, the leader was led by a Religious Leader in Gumeng Village. As in religious characteristics, they are, involved in socio-religious groups, therefore as good religious people should carry out religious ritual activities such as this Mandhasiya tradition, where Gumeng villagers enthusiastically on Tuesday Kliwon Wuku Mandhasiya on July $19^{\text {th }}$, 2018, right at 8:00 a.m. West Indonesia Time held a prayer together in the courtyard of Cetho Temple. They bring offerings from their homes with full of sincerity to offer to God the Almighty as a form of gratitude for the gifts that have been given.

After making a collective prayer, the community members together perform festivity (eating together) from the provisions brought from home. Gumeng villagers in their religious practices do not discriminate between religions with each other, they mingle with all the people and feel that they are a unity. 


\subsubsection{Community Welfare}

The implementation of the Mandhasiya tradition is a tradition that is always awaited by the Gumeng villagers. The Mandhasi tradition has the effect of realizing people's welfare. This can be seen from the participation of the community in the procession of the Mandhasiya tradition which is a spiritual need which is the achievement of physical and spiritual wellbeing. In this case, welfare has many meanings, such as mental well-being as well as material, but in essence, this prosperity is to expect a safe, peaceful, secure, and happy life.

By implementing the Mandhasiya tradition, the community feels that their inner well-being is fulfilled. People feel that when their hearts are happy, they will bring peace to themselves. The community also wants an interaction process that should be built between Gumeng village community members. Thus, the community life in Gumeng Village will get peace and safety, and there will be no conflict between community members.

Based on the explanation above, welfare is not only from fulfilling material or economic factors but also from fulfilling the values of social interaction that goes well in an effort to achieve welfare.

\section{Conclusion}

The Gumeng village community still maintains this Mandhasiya tradition because of several reasons, they are: a) the desire to preserve Javanese culture, b) asking for salvation to the Almighty God, c) maintaining harmony among the people, and d) the existence of public trust in myth.

The values of local wisdom in the Mandhasiya tradition include: a) religious value: that in the implementation of the Mandhasiya tradition, the community has the belief that the macrocosm and microcosm are maintained and the balance of nature is maintained, by offering prayers in the Cetho Temple courtyard, b) togetherness value: value is created in the community where they blend in various religions. They do mutual cooperation and work together to create familiarity with the community, c) environmental conservation value, in this case the Gumeng villagers carry out cleaning and community service activities both in the temple area and around them so that the village's beauty and cleanliness are maintained, d) Sincerity value, Gumeng villagers carry out this tradition with full of sincerity as starting when collecting funds, they are donating funds and actively participate in the implementation of this procession.

The implications of the implementation of this Mandhasiya tradition on the life of the Gumeng villagers are as follows: a) strengthening community religiosity, this can be seen from the enthusiasm of the community by holding a joint prayer to Hindus one day before the procession of the tradition, and during this traditional procession, b) strengthening solidarity, this can be seen from the involvement of the community from the preparation stage to the final stage of the Mandhasiya tradition, c) Engaging in collective worship, where the community both Muslims, Christians, and Hindus bring offerings to the cetho temple court to be presented as a form of gratitude, and d) the welfare of the community, by carrying out this transformation the Gumeng villagers felt they would be more peaceful, prosperous, and happy.

\section{References}

Anggoro, Bayu. 2017. Mandhasiya : Tradisi Dan Eksotisme Upacara Warisan Leluhur Hindu Jawa. Prosiding Seminar Nasional Sejarah Lokal. Tanggal 26 April 2017.

Basyari, Iin Wariin. H, 2014. Nilai-nilai Kearifal Lokal (Local Wisdom) Tradisi Memitu Pada Masyarakat Cirebon (Studi Masyarakat Desa Setupatok Kecamatan Mundu). Jurnal Edunomic, Vol.2 No.1. 
Ernawi, SM. 2010. Harmonisasi Kearifan Lokal Dalam Regulasi Penataan Ruang (online). Makalah Pada Seminar Nasional, Urban Culture, Urban Future.

(http://www.penataanruang.net). 26 Desember 2017.

Ira Indrawardana. 2012. Kearifan Lokal Adat Masyarakat Sunda Dalam Hubungannya Dengan Lingkungan Alam. Jurnal Komunitas.

Iskandar. 2010. Metodologi Penelitian Pendidikan dan Sosial (Kuantitatif dan Kualitatif). Jakarta : Gaung Persada Press.

Miles, B. Mathew dan Michael Huberman, 1992. Analisis Data Kualitatif Buku Standar Tentang Metode-metode Baru. Jakarta : UIP

Perbowosari, H. (2018, January). Nilai Kearifan Lokal Upacara Perkawinan Adat Keraton Jawa Dalam Perspektif Agama Hindu. In Prosiding Seminar Nasional Kearifan Lokal Indonesia Untuk Pembangunan Karakter Universal 2015 (pp. 80-87).
Ranjabar, Jacobus. 2006. Sistem Sosial Budaya Indonesia : Suatu Pengantar. Bogor : PT. Ghalia Indonesia.

Soares, F., \& Sudarsana, I. K. (2018). Religious Harmony Among Senior High School Students Multicultural Education Case Study in the CovaLima District of East Timor. Vidyottama Sanatana: International Journal of Hindu Science and Religious Studies, 2(1), 154-162.

Suciartini, Ni Nyoman. 2017. Tat Twam Asi Penepis Intoleransi. Prosiding Seminar Nasional Filsafat. Tanggal 17 Maret 2017.

Sudharta dan Atmaja, 2001. Upadesa Tentang Ajaran-Ajaran Agama Hindu, Surabaya : Paramita Surabaya.

Sujamto. 1992. Refleksi Budaya Jawa. Semarang : Effhar dan Dahara Prize.

Suparlan, Supardi. 1984. Manusia, Kebudayaan dan Lingkungannya. Jakarta : CV. Rajawali.

Sztompka, Piotr. 2007. Sosiologi Perubahan Sosial. Jakarta : Prenada Media Grup.

Titib, I Made. 1996. Veda Sabda Suci Tuhan : Pedoman Praktis Kehidupan. Surabaya : Penerbit Paramita. 